\title{
ЗАПОБІГАННЯ КОРУПЦІЇ НА ПУБЛІЧНІЙ СЛУЖБІ: ПРАВОВЕ РЕГУЛЮВАННЯ В УКРАЇНІ ТА ДОСВІД КРАЇН ЄВРОПЕЙСЬКОГО СОЮЗУ
}

Янюк Н. В.

\section{ВСТУП}

У світі існують країни з різним рівнем захисту прав і свобод людини та рівнем економічного розвитку, проте немає країни, якій би вдалося абсолютно подолати прояви корупції. Деякі країни значно знизили показник корупції, однак і в цих країнах є сфери, в яких існують корупційні ризики, а тому запроваджуються додаткові антикорупційні заходи. У будь-якій державі найбільш вразливою сферою залишається публічна служба. 3 приводу цього можна назвати дві основні причини. По-перше, публічний службовець є представником держави, а тому $\epsilon$ носієм частини владних повноважень, що вимагає встановлення певного балансу їх використання, аби не допустити зловживання, перевищення чи неналежного використання у приватних інтересах. Сама назва «публічний службовець» має відображати служіння в публічних інтересах. По-друге, публічний службовець найчастіше перебуває у відносинах із пересічними громадянами і від його поведінки залежить репутація відповідного органу влади, формується довіра до публічної адміністрації загалом. Безперечно, важливим фактором залишається внутрішнє переконання самого публічного службовця діяти правомірно. Разом із тим створюють механізм протидії незаконному впливу з боку інших осіб на публічного службовця.

Види заходів протидії корупції можуть відрізнятися у країнах, деякі з них стали певними стандартами і відмінність може стосуватися лише тривалості їх дії чи сфери застосування. Основною метою наукового дослідження стало питання правового регулювання запобігання корупції на державній службі і службі в органах місцевого самоврядування в Україні (як ключових складниках публічної служби), аналіз антикорупційного законодавства і вивчення позитивних змін, що відбулися внаслідок запровадження позитивного досвіду країн-членів СС.

\section{1. Антикорупційне законодавство: поняття та сфера застосування}

Упродовж останніх десятиліть в обігу широко використовується термін «антикорупційне законодавство». В українській юридичній термінології його появу пов'язують із прийняттям Закону України 
«Про боротьбу з корупцією» (1995р.). Варто з’ясувати розуміння самого терміна «законодавство», а це допоможе визначити структуру антикорупційного законодавства. Найчастіше питання щодо розуміння терміна «законодавство» виникає під час дослідження джерел права в межах відповідної галузі. Наприклад, у Томі 1. Академічного курсу «Адміністративне право України» під адміністративним законодавством визначено «систему нормативно-правових актів, в яких містяться найбільш загальні й важливі адміністративно-правові норми». У подальшому конкретизовано, що до таких актів належать відповідні акти Верховної Ради, Президента України і Кабінету Міністрів України. Серед переліку названо так зване «відомче законодавство», тобто нормативно-правові акти міністерств та інших центральних органів виконавчої влади у тих випадках, коли вони визначають права і обов'язки громадян. ${ }^{1}$ Такий підхід свідчить про широке розуміння терміна, однак у визначенні не згадано про міжнародні акти, згода на обов'язковість яких надана Верховною Радою України.

Проте $є$ й вузьке розуміння терміна «законодавство» винятково як сукупності законів. Зокрема, виник спір щодо положення ч. 3 ст. 21 Кодексу законів про працю України і було звернення за офіційним тлумаченням до Конституційного Суду України (далі - КСУ). КСУ 9 липня 1998 р. розглянув справу щодо тлумачення терміна «законодавство» і звернув увагу на те, що термін широко використовується у правовій системі в значенні «сукупності законів та інших нормативно-правових актів, які регламентують ту чи іншу сферу суспільних відносин джерелами певної галузі права». Відповідно до Рішення КСУ терміном «законодавство» охоплюються «закони України, чинні міжнародні договори України, згода на обов'язковість яких надана Верховною Радою України, а також постанови Кабінету Міністрів України, укази Президента України, декрети і постанови Кабінету Міністрів України, прийняті в межах їх повноважень та відповідно до Конституції України і законів України»².

Іноді зустрічається наукова дискусія щодо необхідності додаткового виокремлення міжнародних актів як різновиду законодавства, переважно це виникає в контексті дослідження теми джерел права. Наприклад, О.М. Ордіна міжнародні акти, що містять загальновизнані

\footnotetext{
1 Академічний курс «Адміністративне право України» : Підручник: у двох томах: Том 1. Загальна частина / Ред. Колегія: В.Б. Авер’янов (голова). Київ : Вид-во «Юрид. Думка», 2004. C. 147.

2 Рішення Конституційного Суду України від 9 липня 1998 р. (справа про тлумачення терміна «законодавство»). URL: https://zakon.rada.gov.ua/laws/show/v012p710-98
} 
принципи та норми міжнародного права, міжнародні договори зарахувала до «нетрадиційних джерел адміністративного права»³. Проте з таким підходом слушно не погоджується професор В.В. Решота, який звертає увагу, що «належним чином ратифіковані міжнародні договори стають частиною національного законодавства й можуть застосовуватись поряд iз нормативними актами» ${ }^{4}$. У такому разі термін «законодавство» охоплює як чинні національні нормативно-правові акти, так і міжнародні акти, які, згідно зі ст. 9 Конституції України, в разі надання згоди на їх обов'язковість Верховною Радою України за встановленою процедурою стають частиною національного законодавства України.

Порівняно новим є поняття «акти «м'якого права» (3 англ. soft law), які спочатку розглядались у контексті джерел міжнародного права. Нині серед учених-адміністративістів ще не вироблено єдиного бачення щодо їх зарахування до джерел адміністративного права. T.О. Коломоєць наводить аргументи науковців на користь їх допоміжної ролі у «становленні або визначенні правової думки, підготовці і розробці договірних міжнародно-правових норм, а також внутрішньодержавних юридичних актів». Маючи рекомендаційний характер, акти «м’якого права» (soft law) відіграють вжливу роль у гармонізації міжнародного та національного законодавства ${ }^{5}$.

Вдало підкреслила значення таких актів О.О. Щокіна, вказавши, що нині «м’яке право» визначає вектор розвитку певних відносин на національному рівні, а також виступає інструментом гармонізації національних законодавств. Науковець також зазначила, що «м’яке право» опосередковано впливає на регулювання відносин, сприяючи запровадженню міжнародних стандартів у національне законодавство. ${ }^{6}$ Разом iз тим В.В. Решота додає, що часто вони супроводжують переговорний процес, процес підписання нормативних договорів і застосовувати їх як джерело є добровільною справою відповідного суб'єкта. На його думку, це дає змогу зарахувати акти «м'якого права» до джерел переконливого характеру, що можуть застосовувати суди ${ }^{7}$.

\footnotetext{
3 Ордина О.Н. Источники административного права России и проблемы их систематизации : монография. Москва : ЮНИТИДАНА, 2015. С. 50-51.

4 Решота В.В. Джерела адміністративного права України: проблеми судового застосування : монографія. Львів : ТОВ «Галицька видавнича спілка», 2018. С. 41.

5 Коломоєць Т.О. Джерела адміністративного права: проблемні питання доктринального визначення, класифікації та системного аналізу. Право Украӥни. 2017. № 6. С. 75.

6 Щокіна О.О. «М'яке право» системи регулювання корпоративних відносин. Теорія і практика правознавства. 2018. Вип. 2 (14). С. 136.

7 Решота В.В. Джерела адміністративного права України: проблеми судового застосування : монографія. Львів : ТОВ «Галицька видавнича спілка», 2018. С. 280.
} 
Отже, поняття «законодавство» охоплює чинні акти різної юридичної сили. Акти «м'якого права» не зараховують до законодавства, однак вони мають вагоме значення для узгодження національного законодавства з європейськими стандартами в певній сфері, зокрема публічно-службових відносинах і питаннях запобігання корупції, що знаходяться в тісному взаємозв'язку.

Жоден законодавчий акт не містить поняття «антикорупційне законодавство». Це поняття є збірним і стосується різних за юридичною силою актів, які передбачають заходи запобігання, припинення корупційних діянь і встановлюють відповідальність за такі дії. Автори Науково-практичного коментаря до Закону України «Про боротьбу 3 корупцією» під цим поняттям пропонують розуміти «закони та інші нормативно-правові акти, якими встановлюються спеціальні законодавчі положення щодо запобігання корупції, виявлення та припинення iї проявів, визначаються ознаки корупційних правопорушень та відповідальність за їх вчинення, регулюється діяльність державних органів чи їх спеціальних підрозділів, до компетенції яких входить протидія корупції, координація такої діяльності чи контроль та нагляд за нею».

Мета антикорупційного законодавства полягає в тому, щоб: 1) обмежити чи усунути фактори корупції в діяльності органів публічної адміністрації, шляхом визначення системи обмежень і заборон певним колом осіб; 2) визначити уповноважених суб'єктів та механізм контролю за особами, на яких поширюється дія антикорупційного законодавства; 3) встановити заходи відповідальності за порушення антикорупційного законодавства.

Антикорупційне законодавство становлять акти, які безпосередньо стосуються запобігання і протидії корупції. Однак в інших нормативно-правових актах можуть міститися норми, які спрямовані на запобігання корупції. Зокрема, у ч. 2 ст. 19 Конституції України передбачено спеціально дозвільний принцип діяльності органів державної влади, органів місцевого самоврядування та їх посадових осіб - «діяти лише на підставі, в межах повноважень та у спосіб, що передбачені Конституцією та законами України». Антикорупційні заходи були передбачені і в окремих нормативно-правових актах, які регулюють відносини державної служби чи служби в органах місцевого самоврядування. У ч. 2 ст. 5 Закону України «Про державну службу» від 16 грудня 1993 р. вперше було закріплено низку обмежень, які мали запобігти проявам

8 Мельник М.I., Редька А.І., Хавронюк M.I. Науково-практичний коментар Закону України «Про боротьбу з корупцією»/За заг. ред. М.І. Мельника. Київ : Атіка, 2008. С. 4. 
корупції, зокрема державному службовцю заборонялося «брати участь у діях, що суперечать національним інтересам України, ускладнюють функціонування державних органів; вчиняти дії, що можуть бути розцінені як використання свого службового становища в корисливих цілях у власних інтересах, а також дії, які відповідно до чинного законодавства вважаються корупційними; виявляти всупереч інтересам справи упередженість або прихильність до будь-якого підприємства, установи, організації, органу, об'єднання громадян чи конкретної особи; проявляти бюрократизм, відомчість і місництво». 5 жовтня 1995 р. був прийнятий Закон України «Про боротьбу з корупцією», до якого було зараховано згадані обмеження державного службовця. Закон України «Про боротьбу з корупцією» став першим антикорупційним законом. Однак його прийняття не вирішило проблем у системі органів публічної влади. У Законі були передбачені заходи адміністративної і дисциплінарної відповідальності за порушення встановлених обмежень та заборон, але не було закріплено превентивних заходів, які давали б змогу публічному службовцю самостійно усунути ситуації, що містили корупційні ризики. У Законі не згадувалося про конфлікт інтересів, який лежить в основі корупційних діянь.

Важливе значення на шляху формування антикорупційного законодавства мала ратифікація міжнародних актів у сфері протидії корупції. Верховна Рада України 18 жовтня 2006 р. прийняла Закон «Про ратифікацію Конвенції ООН проти корупції ${ }^{9}$. Прийняття Конвенції ООН проти корупції 31 жовтня 2003 р. (далі - Конвенції) було зумовлено стурбованістю зв'язком корупції з іншими злочинами, які підривають економічний розвиток держав, зокрема «організованою злочинністю й економічною злочинністю». У Преамбулі до Конвенції наголошується, що корупція перестала бути «локальною проблемою», має вплив на всі країни, а тому «зумовлює винятково важливе значення міжнародного співробітництва в галузі запобігання корупції та контролю за нею». 3 огляду на це Закон України «Про боротьбу з корупцією» потребував перегляду на предмет узгодження із завданнями, які взяла на себе Україна у сфері запобігання корупції. Окрема увага в Конвенції приділялася заходам запобігання для державних посадових осіб, тобто тим, хто «виконує державну функцію» або надає «державну послугу». Державам-учасницям було рекомендовано врегулювати питання етики поведінки таких осіб, прийнявши

\footnotetext{
9 Про ратифікацію Конвенції ООН проти корупції : Закон України від 18 жовтня 2006 р. URL: https://zakon.rada.gov.ua/laws/show/251-16
} 
«кодекси або стандарти поведінки для привального, добросовісного й належного виконання державних функцій».

Підготовка пакету антикорупційного законодавства в Україні розпочалася ще у 2005 р. й до участі були залучені науковці, практики, міжнародні експерти. Після тривалої і копіткої роботи у червні 2009 р. було прийнято у першій редакції Закон України «Про засади запобігання і протидії корупції», проте деякі положення закону Конституційним Судом України були визнані неконституційними, що стало підставою для подальшого його доопрацювання і остаточно процес завершився лише 7 квітня 2011 р., а Закон України «Про засади запобігання і протидії корупції» набув чинності з 1 липня 2011 р. Цей Закон зумовив потребу переглянути положення законодавства про державну службу і службу в органах місцевого самоврядування на предмет їх відповідності щодо вжиття антикорупційних заходів. 3'явилося законодавче закріплення поняття «конфлікт інтересів» і обмеження обійняття посади державної служби чи служби в органах місцевого самоврядування у разі існування конфлікту інтересів. Законом України «Про засади запобігання і протидії корупції» введено новий термін «близькі особи», що передбачав ширше коло осіб, аніж наявні терміни «родичі» i «свояки». У Законі України «Про засади запобігання і протидії корупції» 3'явилися норми, які передбачили обмеження щодо одержання дарунків (пожертв), урегулювання конфлікту інтересів, що відповідало ч. 4 ст. 7 Конвенції, зокрема передбачено створення, підтримку й зміцнення таких систем, які «сприяють й запобігають виникненню конфлікту інтересів», та ч. 5 ст. 8, де йдеться про «суттєві дарунки і прибутки, у зв'язку з якими може виникнути конфлікт інтересів стосовно їхніх функцій як державних посадових осіб». Новелою для національного законодавства стало запровадження обмеження після припинення діяльності, пов'язаної з виконанням функцій держави, місцевого самоврядування, що відповідало положенню п. е) ч. 2 ст. 12 Конвенції.

Законодавець також переглянув нормативне регулювання поведінки державних службовців. Відповідно до ст. 13 Закону України «Про засади запобігання і протидії корупції» Верховною Радою України 17 травня 2012 р. було прийнято Закон України «Про правила етичної поведінки». Однак назва цього Закону не відображала ні кола осіб, ні межі його регулювання. У законі недостатньо було визначено понятійний апарат. Окремі положення Закону України «Про правила етичної поведінки» відображали пропозиції, викладені у Рекомендаціях Комітету Міністрів Ради Європи № R (2000) 10 щодо 
кодексів поведінки державних службовців (від 11 травня 2000 р.), а саме Модельного Кодексу поведінки публічних службовців, який є Додатком до Рекомендацій. У ст. 9 Модельного кодексу передбачено, що публічний службовець зобов'язаний діяти таким чином, щоб «була забезпечена віра громадськості в чесність, безсторонність і ефективність публічної влади». Подібне положення містила ст. 12 Закону України «Про правила етичної поведінки». У ст. 8 Модельного кодексу зазначено, що публічний службовець не має допускати конфлікту інтересів. Відповідно, у ст. 15 Закону України «Про правила етичної поведінки» зазначалось, що такі особи мають вжити «вичерпних заходів щодо недопущення конфлікту інтересів», а також не допустити враження про їх наявність. Проте у згаданому Законі питання відповідальності за порушення правил етичної поведінки були викладені в узагальненій формі, не враховував такої відповідальності і чинний на той час Закон «Про державну службу» (1993 р.). Нову редакцію Закону України «Про державну службу» було прийнято 17 листопада 2011 р., в ньому вже було зазначено, що порушення правил професійної етики державного службовця є однією з підстав для притягнення державного службовця до дисциплінарної відповідальності ${ }^{10}$. Однак дата вступу в дію цього Закону постійно змінювалась і за цей час був прийнятий новий антикорупційний закон, бо практика виявила недоліки останнього. Висловлюючи деякі критичні міркування, М.I. Хавронюк звернув увагу на неточність назви закону. На його думку, цей Закон можна було б назвати Законом України «Про запобігання корупції і протидію корупцію» або, «якщо вважати запобігання корупції одним із напрямів протидії їй, ще лаконічніше - «Про протидію корупції» - за аналогією з відомою Конвенцією ООН». ${ }^{11}$ У Законі також нечітко було окреслено систему органів, які мали здійснювати контроль за дотриманням антикорупційного законодавства, не було визначено способів врегулювання конфлікту інтересів та ін.

Закон України «Про запобігання корупції» був прийнятий Верховною Радою України 14 жовтня 2014 р. ${ }^{12}$ Колектив Запорізького національного університету позитивно оцінив цей Закон як «комплекс політико-правових заходів, спрямованих, по-перше, на формування

10 Янюк Н. Актуальні проблеми у регулюванні питань професійної етики публічних службовців. Вісник Львівського університету. Серія юридична. 2013. Вип. 57. С. 206.

11 Хавронюк М.I. Науково-практичний коментар до Закону України «Про засади запобігання і протидії корупції». Київ : Атака, 2011. С. 10.

12 Про запобігання корупції : Закон України від 14 жовтня 2014 p. URL: https://zakon.rada. gov.ua/laws/show/1700-18 
антикорупційного налаштування суспільства, по-друге, підвищення обізнаності громадськості про небезпеки, що пов'язані з корупцією, по-третє, забезпечення міжнародних стандартів щодо кваліфікації корупційних правопорушень, по-четверте, створення атмосфери прозорості в діяльності з виявлення фактів корупції, по-п'яте, виховання поваги до принципу невідворотності покарання, по-шосте, забезпечення справедливого відшкодування збитків особам, які постраждали від корупційних діянь» ${ }^{13}$.

У Законі України «Про запобігання корупції» зменшено кількість банкетних норм, безпосередньо визначено статус Національного агентства 3 питань запобігання корупції як органу, який покликаний забезпечити формування та реалізацію державної антикорупційної політики. Відповідно до ч. 1 ст. 37 Закон став правовою основою для кодексів чи стандартів професійної етики. Загальні правила поведінки державних службовців та посадових осіб місцевого самоврядування були затверджені Наказом Національного агентства 3 питань державної служби від 05.08.2016 р. № 158.

У ст. 55 Закону України «Про запобігання корупції» передбачено основні вимоги щодо проведення антикорупційної експертизи. Поряд 3 обов'язковою антикорупційною експертизою, яку проводить Міністерство юстиції України, законодавець передбачив можливість проведення громадської антикорупційної експертизи чинних нормативно-правових актів і проектів таких актів.

Прийняття основного антикорупційного закону зумовило необхідність переглянути інші закони, які стосуються діяльності органів публічної влади, а то й оновити законодавчу базу, зокрема 10 грудня 2015 р. був прийнятий новий Закон України «Про державну службу» ${ }^{14}$.

Підписавши та ратифікувавши Конвенцію ООН проти корупції і приєднавшись до Цивільної та Кримінальної конвенцій про боротьбу з корупцією, Україна приєдналася до міжнародних інституцій, діяльність яких спрямована на пошук дієвих способів протидії корупції. Прийняття антикорупційного законодавства 3 урахуванням європейських принципів та стандартів допомагає здійснювати міжнародне співробітництво у сфері запобігання і протидії корупції.

\footnotetext{
13 Науково-практичний коментар Закону України «Про запобігання корупції» / за заг. ред. Т.О. Коломоєць, В.К. Колпакова. Запоріжжя : Видавничий дім «Гельветика», 2019. С. 8

14 Про державну службу : Закон України від 10 грудня 2015 p. URL: http://zakon2.rada.gov. ua/laws/show/889-19
} 


\section{2. Система заходів запобігання корупції на публічній службі: реалії України та досвід країн ЄС}

Хоча сам термін «корупція» $є$ порівняно новим, але відомості про корупційні складники містяться в багатьох історичних джерелах Давнього Єгипту, Китаю, Індії, Давньої Греції й Риму. У біблійній книзі Вихід 23:8 сказано: «Не бери хабара, бо хабар засліплює того, хто судить мудро і перекручує слова праведного». У Мойсеєвому Законі значна увага приділена запобіганню хабарництву і підкупу суддів та правителів. Тема правління і «належного мистецтва правосуддя» стала предметом також вчень Платона, Аристотеля, Цицерона ти інших мислителів давнини. Досліджуючи їхню спадщину, С.П Головатий слушно звертає увагу на те, що вони глибоко роздумували над питанням справедливого управління, наприклад, Аристотель зазначав, що «той, хто хоче справедливо управляти, має спочатку навчитися належним чином виявляти послух». У сучасному розумінні йдеться про «вимогу до посадових осіб, у чиїх руках зосереджено владу, у процес іiі здійснення неухильно керуватися вимогами приписів права» ${ }^{15}$. Вони, в першу чергу, мають запобігати корупції. В основі теорії розподілу влади також була ідея створення механізму протидії корупції - не допустити концентрації влади в одного суб'єкта. Створення механізму взаємного контролю дає змогу запобігти зловживанням владою, яку особа отримує з часу вступу на службу.

Вперше в Україні визначення поняття «корупція» було закріплено в Законі України «Про боротьбу з корупцією» 1995 р. У кожній новій редакції основного антикорупційного закону поняття «корупція» уточнювалося. Про посилення протидії корупції йдеться в Угоді про Асоціацію між Україною і Свропейським Союзом ${ }^{16}$. У Додатку XLIII до Розділу VI «Фінансове співробітництво та положення щодо боротьби із шахрайством» визначено два види корупції - активну i пасивну. Обидва види передбачають умисну форму вчинення і завдають чи можуть завдати шкоди фінансовим інтересам ЄС. Отже, Україна має вжити заходів із запобігання проявам таких діянь і припинення в разі їх виявлення.

В.М. Трепак визначає корупцію як «соціальне, системне явище, що полягає в неправомірному використанні особами, які мають владні

\footnotetext{
15 Головатий С.П. Верховенство права : монографія : У 3-х кн. Київ : Вид-во «Фенікс», 2006. Кн. 1-a. C. 82.

16 Угода про Асоціацію між Україною і Європейським Союзом. URL: http://eu-ua.org/ tekst-uhody-pro-asotsiatsiiu
} 
чи управлінські повноваження, власного становища, статусу, авторитету в особистих або корпоративних інтересах, що призводить до розкладання, деградації влади та соціального управління» ${ }^{17}$. Через необхідність мінімізації негативних проявів корупції необхідним $є$ пошук оптимального законодавчого регулювання протидії такому явищу.

Чинний Закон України «Про запобігання корупції» (2014р.) визначив коло суб'єктів, на яких поширюється дія цього Закону, визначив види дій, які підпадають під поняття «корупція». У Законі не лише визначено поняття «корупція», але й розмежовано поняття «корупційні правопорушення» i «правопорушення, пов'язані 3 корупцією». Остання категорія стосується діянь, які не містять ознак корупції, однак стосуються порушень, встановлених обмежень і заборон. Найчастіше суб'єктом таких правопорушень стають публічні службовці. До заходів, спрямованих на запобігання корупції на публічній службі, варто зарахувати: 1) законодавче врегулювання обмежень і заборон під час проходження публічної служби; 2) запобігання чи усунення конфлікту інтересів; 3) визначення ознак та видів корупційних правопорушень і правопорушень, пов'язаних із корупцією та закріплення адекватних заходів відповідальності за їх вчинення; 4) врегулювання статусу органів державної влади, які здійснюють протидіють корупції. За часом проведення можна виділити три види заходів: 1) перед вступом на посаду - спеціальна перевірка щодо осіб, які претендують на обійняття посад, пов'язаних із виконанням функцій держави, місцевого самоврядування; 2) під час проходження служби/перебування на посаді: щодо обмеження використання службових повноважень чи свого становища; щодо дотримання правил сумісництва та суміщення з іншими видами діяльності; щодо вимог одержання подарунків; щодо обмеження спільної роботи близьких осіб; щодо фінансового звіту подання декларацій про майновий стан; щодо запобігання та врегулювання конфлікту інтересів; 3) після припинення служби/діяльності, пов'язаної з виконанням функцій держави, місцевого самоврядування.

О.Б. Червякова слушно зазначає, що відмінності між заборонами та обмеженнями в Законі України «Про запобігання корупції» не закріплені. На ii думку, варто виокремити заборони: використання службових повноважень чи свого становища 3 метою одержання неправомірної вигоди (ст. 22 Закону); вимагання одержання подарунків (ч. 1 ст. 23 Закону) та обмеження: прийняття подарунків

17 Трепак В.М. Особливості дефініції поняття «корупція». Науковий вісник Національної академії внутрішніх справ. 2015. № 4. С. 192. 
(ч. 1 ст. 23 Закону); сумісництво та суміщення з іншими видами діяльності (ст. 25 Закону); обмеження щодо спільної роботи близьких осіб (ст. 27 Закону); окремі обмеження після припинення діяльності, пов'язаної з виконанням функцій держави, місцевого самоврядування (ст. 26 Закону). До тимчасових обмежень варто зарахувати зупинення членства у політичній партії для осіб, які претендують на заміщення посади державної служби категорії «А», згідно з ч. 3 ст. 10 Закону «Про державну службу» ${ }^{18}$.

Науковці роблять висновок, що правові обмеження в загальному їх вигляді мають превентивний характер і убезпечують від можливих несприятливих наслідків як суб'єктів, щодо яких діють ці обмеження, так і інших осіб. Вони «зводяться до справедливої впорядкованості суспільних відносин шляхом встановлення кордонів, що обмежують допустимість поведінки» ${ }^{19}$.

У ст. 23 Закону України «Про запобігання корупції» (2014р.) передбачено обмеження щодо одержання подарунків. Відповідно до ст. 1 цього ж Закону подарунок - це «грошові кошти або інше майно, переваги, пільги, послуги, нематеріальні активи, які надають/одержують безоплатно або за ціною, нижчою за мінімальну ринкову». Обмеження щодо одержання подарунків добре відоме законодавству країн СС. В Україні тривалий час точилася гостра дискусія з приводу того, чи заборонити взагалі приймати подарунки, чи дозволити їх приймати, встановивши певні граничні розміри і визначивши певний порядок. Зрештою, був досягнутий компроміс і передбачено, що особам, уповноваженим на виконання функцій держави або місцевого самоврядування, у зв'язку із здійсненням службової діяльності забороняється безпосередньо або через інших осіб вимагати, просити, одержувати подарунки для себе чи близьких осіб від юридичних або фізичних осіб, також забороняється одержувати подарунки від особи, яка перебуває в їх підпорядкуванні. У ч. 2 ст. 23 цього Закону є окремі винятки, проте визначено умови правомірності дій у процесі одержання подарунка, зокрема особи, перелік яких визначений у п.п. 1, 2 ч. 1. ст. 3 Закону, можуть приймати подарунки, які відповідають загальновизнаним

\footnotetext{
18 Червякова О.Б. Антикорупційні стандарти державної служби. Актуальні питання реалізачї нового Закону України «Про державну службу»: збірник матеріалів Всеукраїнського форуму вчених-адміністративістів. Запоріжжя, 2016. С. 172.

19 Шимон О.М. З'ясування сутності понять «обмеження» та «заборони» у сфері запобігання адміністративним правопорушенням, пов'язаними із корупцією. Вісник Запорізького національного університету. 2017. № 4. С. 80.
} 
уявленням про гостинність, якщо вартість таких подарунків не перевищує одного прожиткового мінімуму для працездатних осіб, встановленого на день прийняття подарунка, одноразово, а сукупна вартість таких подарунків, отриманих від однієї особи (групи осіб) протягом року, не перевищує двох прожиткових мінімумів, встановлених для працездатної особи на 1 січня того року, в якому прийнято подарунок. Разом із тим обмеження щодо вартості подарунків не поширюється на подарунки, які: 1) даруються близькими особами; 2) одержуються як загальнодоступні знижки на товари, послуги, загальнодоступні виграші, призи, премії, бонуси.

Професор Т.О. Коломоєць слушно зауважує, що важливою ознакою обмеження є вартість подарунка. На їі думку, вартісна ознака важлива саме щодо обмежених (лімітованих), звичайних подарунків, які певним чином пов'язані із службовою діяльністю особи й надходять, як правило, не від близьких осіб, однак які не передбачають будь-якого впливу на об'єктивність, неупередженість публічної діяльності особи. Саме такі подарунки варто розглядати як «заздалегідь незапланований прояв «поваги, вдячності, шани» за сумлінну професійну правомірну діяльність особи, який не вимагає будь-якої зворотної реакції з боку особи, яка отримала подарунок». Максимальна вартісна межа може фіксуватися й у «твердому розмірі» й не прив'язуватися до певного коефіцієнта, який може змінюватися, з урахуванням реалій життя та пріоритетів внутрішньої політики держави, зокрема останній варіант обрано в Україні ${ }^{20}$.

Законодавець визначив алгоритм дій у разі надходження пропозиції щодо неправомірної вигоди або подарунка: 1) відмовитися від пропозиції; 2) за можливості ідентифікувати особу, яка зробила пропозицію; 3) залучити свідків, якщо це можливо, у тому числі з числа співробітників; 4) письмово повідомити про пропозицію безпосереднього керівника (за наявності) або керівника відповідного органу, підприємства, установи, організації, спеціально уповноважених суб'єктів у сфері протидії корупції. Згідно зі ст. 24 Закону України «Про запобігання корупції» визначено певний порядок дій під час виявлення подарунка: 1) у службовому приміщенні; 2) за місцем проживання; 3) під час перебування у громадських місцях.

\footnotetext{
20 Коломоєць Т.О. Подарунок для публічного службовця: вартісна межа дозволеного (порівняльно-правовий аналіз досвіду України та зарубіжних країн). Корупційні ризики в публічній службі: компаративно-правовий аналіз досвіду крайн східної та західної традицій nрава»: тези доповідей регіонального науково-практичного круглого столу, Запоріжжя, 28-29 березня 2018 р. / за заг. ред. Т.О. Коломоєць. С. 97.
} 
У разі виникнення сумнівів щодо можливості одержання подарунка особа право письмово звернутися для отримання роз'яснення з цього приводу до Національного агентства 3 питань запобігання корупції (далі - НАЗК). Логічним було б доповнити статтю положенням, що «в разі вчинення дій відповідно до наданого НАЗК роз'яснення, вважається, що особа діє правомірно».

Інститут обмеження прийняття подарунків може відрізнятися в країнах. Наприклад, у § 70 Федерального закону про статус чиновника Німеччини закріплено заборону приймати подарунок під час і служби і після закінчення службових відносин, якщо подарунок пов'язаний із попередньою посадою ${ }^{21}$. Натомість у законодавстві Сінгапуру передбачено, що публічний службовець у разі неможливості відмовитися від одержання подарунку (за протоколом візиту іноземної делегації) може його прийняти й негайно передати керівникові свого департаменту, або може й викупити. Аналогічне правило щодо так званих «вимушених» подарунків передбачено й у законодавстві Бразилії. Інший підхід у грузинському законодавстві: а) правила поводження із подарунками регламентовані не лише стосовно публічних службовців, а й членів їхньої родини; б) істотно розширене коло випадків «подарункових відносин» як коштом «контактних» (подарунок вручається публічно), так i «безконтактних» (подарунок отримується поштою); в) відсутні положення із припущеннями («по можливості», «якщо це є можливим»); г) повідомити потрібно негайно, не пізніше трьох робочих днів до Бюро публічної служби (ст. 5-2 Закону Грузії «Про несумісність інтересів та корупції у публічній установі» $)^{22}$.

Законодавством багатьох країн СС передбачено обмеження сумісництва і суміщення службової діяльності 3 іншими оплачуваної діяльності. Як правило, без окремого дозволу публічний службовець може займатися викладацькою, науковою і творчою діяльністю, медичною практикою, інструкторською та суддівською практикою зі спорту, що закріплено у ст. 25 Закону України «Про запобігання корупції». На практиці виникає проблема щодо розуміння понять «медична практика» й «інструкторська або суддівська практика із спорту», що зумовлено відсутністю у законах їх визначення. Сьогодні

21 Федеральний закон про статус чиновника Німеччини : Публічна служба. Зарубіжний досвід та пропозиції для України / За заг. ред. Тимощука В.П., Школика А.М. Київ : Конус-Ю, 2007. C. 248.

22 Коломоєць Т.О., Кукурудз Р.О. Правила поводження публічних службовців із подарунками: компаративно-правовий аналіз (на прикладі досвіду України, Грузії, Сінгапуру, Бразиліі). Вісник Запорізького національного університету. 2018. № 2. С. 76-77. 
чинними є Постанова Кабінету Міністрів України від 2 березня 2016 р. № 285 «Про затвердження ліцензійних умов провадження господарської діяльності з медичної практики» та Наказ Міністерства охорони здоров'я України від 28.02.2020 р. № 593 «Про ліцензування медичної практики закладі», проте і в них не міститься визначення згаданих термінів. Подібна ситуація в Законі України від 24 грудня 1993 р. «Про фізичну культуру і спорт», в якому визначено поняття «спортивний суддя», але відсутнє тлумачення поняття «інструкторська та суддівська практика зі спорту».

У §66 Федерального закону про статус чиновників Німеччини додатково згадано про можливість роботи за сумісництвом без дозволу, якщо це стосується дослідницької діяльності, лекційної діяльності чи підготовки висновків викладачами вищих державних навчальних закладів і вищих навчальних закладів Бундерсверу. Проте «будь-яка робота за сумісництвом, у тому числі й та яка не потребує дозволу, забороняється повністю або частково, якщо чиновник при її виконанні порушує службові обов'язки» (ч. 2 §66 Федерального закону).

У ст. 27 Закону України «Про запобігання корупції» передбачено обмеження спільної роботи близьких осіб, при цьому поняття «близька особа» у ст. 1 цього Закону визначено досить широко. Наприклад, у Законі про цивільну службу Польщі обмеження стосується чоловіка і дружини, а також осіб, з якими є родинні зв'язки до другого ступеню включно, або усиновлення, опіка чи піклування (ст. 79) ${ }^{23}$. У 16 Закону про публічну службу Естонії до них належать: дід, баба, брати, сестри, діти, онуки чи особи, які є свояками внаслідок одруження - чоловік/ дружина, батьки, брати, сестри, діти іншого члена подружжя ${ }^{24}$.

Відповідно до вимог ст. 12 Конвенції ООН проти корупції в антикорупційному законодавстві країн СС передбачені обмеження, які діють після припинення діяльності, пов'язаної з виконанням функцій держави чи місцевого самоврядування. Переважно відмінним є строк дії таких обмежень. Згідно зі ст. 26 Закону України «Про запобігання корупції» обмеження встановлені на один рік, за винятком розголошення або використання в інший спосіб інформації, яка стада відома у зв’язку з виконанням службових повноважень. Наприклад, у ст. 74 Закону про публічну службу Естонії передбачено, що

23 Ustawa z dnia 21listipada 2008 r. O slużbie cywilnej. URL: prawo.sejm.gov.pl/isap.nsf/ DocDetailis.xsp?id=WDU20082271505

24 Публічна служба. Зарубіжний досвід та пропозиції для України / За заг. ред. Тимощука В.П., Школика А.М. Київ : Конус-Ю, 2007. С. 471. 
звільнений із посади державний чиновник не може протягом трьох років із дня звільнення поступати на службу до роботодавця чи ставати членом комерційного об'єднання, за якими він здійснював системний нагляд впродовж останніх трьох років. У §67 Закону Чехії «Про службу» передбачено аналогічне обмеження строком на два роки ${ }^{25}$. У ст. 7 Закону Польщі про організацію ведення господарської діяльності особами, які виконують публічні функції, встановлено один рік обмеження щодо працевлаштування на підприємства, щодо яких особа видавала розпорядчі акти ${ }^{26}$.

Закріплення таких обмежень є обгрунтованим, бо запобігає проявам корупції та зловживанню інформацією, яка стала відомою під час виконання службової діяльності. Практично, законодавче закріплення згаданих вище обмежень спрямоване на недопущення впливу приватного інтересу на об' єктивне і неупереджене виконання завдань публічної служби, а це дає змогу запобігти конфлікту інтересів.

У Додатку XLIII до Розділу VI «Фінансове співробітництво та положення щодо боротьби із шахрайством» під поняттям «конфлікт інтересів» визначено «будь-яку ситуацію, за якої у третьої сторони можуть виникнути або виникають обгрунтовані сумніви щодо спроможності посадових осіб діяти неупереджено і об'єктивно через сімейні обставини, емоційний стан, політичну чи національну приналежність, матеріальні інтереси або спільність будь-яких інтересів з оферентом, аплікантом чи бенефіціаром». В українському законодавстві термін «конфлікт інтересів» спочатку з'явився в підзаконних актах, зокрема в Положенні про організацію внутрішнього аудиту в комерційних банках України, затвердженому Постановою Національного банку України від 20 березня 1998 р. № 114, та Загальних правилах поведінки державного службовця, затверджених наказом Головного управління державної служби України від 23 жовтня 2000 року N 58. Пізніше він був закріплений в антикорупційному законодавстві, а в подальшому в законах про окремі види публічної служби. Закон України «Про запобігання корупції» (2014 р.) визначає два види конфлікту інтересів «потенційний» і «реальний». Адміністративна відповідальність настає за вчинення дій чи прийняття рішення в умовах реального конфлікту інтересів. Однак законодавство про адміністративну відповідальність

25 Публічна служба. Зарубіжний досвід та пропозиції для України / За заг. ред. Тимощука В.П., Школика А.М. Київ : Конус-Ю, 2007. С. 80.

26 Ustawa z dnia 21 sierpnia 1997 r. O ogranichzeniu prowazenia dziatalności gospodarczej rzez osoby pelniące funkcje publiczne. URL: prawo.sejm.gov.pl/isap.nsf/DocDetailis. xsp?id=WDU199710606679 
за правопорушення, пов'язані з корупцією, потребує значного оновлення в частині збирання й оформлення доказів, строків вчинення процесуальних дії.

\section{ВИСНОВКИ}

Нині від України, як і від кожної держави, вимагається проведення системних заходів, спрямованих, по-перше, на виявлення корупціогенних чинників і звуження дискреції в діяльності органів публічної влади, по-друге, на створення механізму запобігання конфлікту інтересів, який є в основі правопорушень, пов'язаних із корупцією, по-третє, на формування системи спеціалізованих правоохоронних органів по виявленню і протидії корупції та забезпечення належного міжнародного співробітництва у цій сфері.

Основою антикорупційного законодавства в Україні є Закон «Про запобігання корупції» (2014р.), в якому першочергово закріплені превентивні заходи щодо корупції. Закони про державну службу і службу в органах місцевого самоврядування, про інші види публічної служби переважно були узгоджені в частині антикорупційних заходів з основним антикорупційним законом. Новий закон про службу в органах місцевого самоврядування й досі не прийнятий, а в чинному мало врегульовано окремі питання, що може зумовити виникнення конфлікту інтересів. Важливе значення мають акти «м'якого права», які не зараховують до законодавства, однак вони сприяють узгодженню національного законодавства з європейськими стандартами.

Переважно антикорупційне законодавство України врахувало досвід європейських країн щодо встановлення обмежень і заборон на публічній службі, способів запобігання та врегулювання конфлікту інтересів, нормативного закріплення правил етичної поведінки публічних службовців. Новелою для національного законодавства стало запровадження обмеження після припинення публічної служб, яке законодавчо закріплено в більшості країн-членів СС. Вартим уваги $\epsilon$ досвід щодо поводження з подарунками, які отримані під час офіційних заходів і вирішення питання щодо можливості їх використання за функціональним призначенням.

Залишилися окремі прогалини щодо понятійного апарату, який використовує антикорупційне законодавство, оціночні категорії, які доводиться тлумачити на практиці, зокрема це підтверджують звернення НАЗК про наукову позицію щодо поняття «суміщення посад», щодо співвідношення понять «близькі особи» і «члени сім’ї» суб’єкта 
декларування, щодо моніторингу способу життя декларанта та деякі інші. Вартим уваги є досвід країн $Є С$, які звужено, порівняно з українським законодавством, тлумачать поняття «близька особа», однак це дає змоги чітко встановити коло таких осіб.

\section{АНОТАЦІЯ}

Основною метою наукового дослідження стало питання правового регулювання запобігання корупції на державній службі і службі в органах місцевого самоврядування в Україні. Антикорупційне законодавство спрямоване на обмеження чи усунення факторів корупції а діяльності органів публічної адміністрації, шляхом визначення системи обмежень і заборон. Важливу роль у гармонізації міжнародного та національного законодавства відіграють акти «м'якого права» (soft law), хоча вони мають рекомендаційний характер. Серед таких актів варто назвати Модельний кодекс публічного службовця, який визначив принципи етичної поведінки публічного службовця і засади запобігання конфлікту інтересів на публічній службі.

Аналіз чинного законодавства дає підстави стверджувати, що антикорупційне законодавство України врахувало досвід країн СС щодо встановлення обмежень і заборон на публічній службі, способів запобігання та врегулювання конфлікту інтересів, нормативного закріплення правил етичної поведінки публічних службовців. Новелою для національного законодавства стало запровадження обмеження після припинення публічної служби, яке законодавчо закріплено в більшості країн-членів ЄС. Окремі відмінності існують щодо термінології, тривалості дії обмежень, порядку поводження з подарунком. Проте нині багато залежить від дієвості державного і громадського контролю у сфері запобігання корупції.

\section{ЛIТЕРАТУРА}

1. Конституція України. URL: https://zakon.rada.gov.ua/laws/show/ 254к/96-вр

2. Конвенція ООН проти корупції (31 жовтня 2003 р.), ратифікована 18 жовтня 2006 р., набрала чинність 1 січня 2010 p. URL: https://zakon.rada.gov.ua/laws/show/995_c16

3. Про державну службу : Закон України від 10.12.2015 p. № 889-VIII. URL: http://zakon2.rada.gov.ua/laws/show/889-19

4. Про запобігання корупції : Закон України від 14 жовтня 2014 р. URL: https://zakon.rada.gov.ua/laws/show/1700-18 
5. Угода про Асоціацію між Україною і Європейським Союзом. URL: http://eu-ua.org/tekst-uhody-pro-asotsiatsiiu

6. Рішення Конституційного Суду України від 9 липня 1998 р. (справа про тлумачення терміна «законодавство»). URL: https://zakon.rada.gov.ua/ laws/show/v012p710-98

7. Ustawa z dnia 21 sierpnia 1997 r. O ogranichzeniu prowazenia dziatalności gospodarczej rzez osoby pelniące funkcje publiczne. URL: prawo.sejm.gov.pl/isap.nsf/DocDetailis.xsp?id=WDU199710606679

8. Ustawa z dnia 21 listipada 2008 r. O slużbie cywilnej. URL: prawo.sejm. gov.pl/isap.nsf/DocDetailis.xsp?id=WDU20082271505

9. Академічний курс «Адміністративне право України» : підручник: у двох томах: Том 1. Загальна частина / ред. колегія: В.Б. Авер'янов (голова). Київ : Вид-во «Юрид. Думка». 2004. 584 с.

10. Головатий С.П. Верховенство права : монографія: У 3-х кн. Київ : Вид-во «Фенікс», 2006. Кн. 1. 624 с.

11. Коломоєць Т.О. Джерела адміністративного права: проблемні питання доктринального визначення, класифікації та системного аналізу. Право України. 2017. № 6. С. 72-79.

12. Коломоєць Т.О. Подарунок для публічного службовця: вартісна межа дозволеного (порівняльно-правовий аналіз досвіду України та зарубіжних країн). Корупиійні ризики в публічній службі: компаративно-правовий аналіз досвіду країн східної та західної традииій права» : тези доповідей регіонального науково-практичного круглого столу, м. Запоріжжя. 28-29 березня 2018 р. / За заг.ред. Т.О. Коломоєць. С. 96-99.

13. Коломоєць Т.О., Кукурудз Р.О. Правила поводження публічних службовців із подарунками: компаративно-правовий аналіз (на прикладі досвіду України, Грузії, Сінгапуру, Бразиліі). Вісник Запорізького національного університету. 2018. № 2. С. 71-79.

14. Мельник М.I., Редька А.І., Хавронюк М.I. Науково-практичний коментар Закону України «Про боротьбу з корупцією» / За заг. ред. М.I. Мельника. Київ : Атіка, 2008. 372 с.

15. Науково-практичний коментар Закону України «Про запобігання корупції» / за заг. ред. Т.О. Коломоєць, В.К. Колпакова. Запоріжжя : Видавничий дім «Гельветика», 2019. 588 с.

16. Ордина О.Н. Источники административного права России и проблемы их систематизации : монография. Москва : ЮНИТИДАНА, $2015.319 \mathrm{c}$.

17. Федеральний закон про статус чиновника Німеччини; Закон про публічну службу Естонії Публічна служба. Зарубіжний досвід та пропозиції для України / За заг. ред. Тимощука В.П., Школика А.М. Київ : Конус-Ю, 2007. 735 с.; Публічна служба. Зарубіжний досвід та пропозиції для 
України / За заг. ред. Тимощука В.П., Школика А.М. Київ : Конус-Ю, 2007. 735 c.

18. Решота В.В. Джерела адміністративного права України: проблеми судового застосування : монографія. Львів : ТОВ «Галицька видавнича спілка», 2018. 384 с.

19. Трепак В.М. Особливості дефініції поняття «корупція». Науковий вісник Національної академії внутрішніх справ. 2015. № 4. С. 181-196.

20. Хавронюк M.I. Науково-практичний коментар до Закону України «Про засади запобігання і протидії корупції». Київ : Атіка, 2011. 424 с.

21. Червякова О.Б. Антикорупційні стандарти державної служби. Актуальні питання реалізації нового Закону України «Про державну службу»: збірник матеріалів Всеукраїнського форуму вченихадміністративістів. Запоріжжя, 2016. С. 171-173.

22. Шимон О.М.3'ясування сутностіпонять «обмеження» та «заборони» у сфері запобігання адміністративним правопорушенням, пов'язаними із корупцією. Вісник Запорізького національного університету. 2017. № 4. C. $79-86$.

23. Щокіна О.О. «М'яке право» системи регулювання корпоративних відносин. Теорія і практика правознавства. 2018. Вип. 2 (14). С. 129-139.

24. Янюк Н. Актуальні проблеми у регулюванні питань професійної етики публічних службовців. Вісник Львівського університету. Серія юридична. 2013. Випуск 57. С. 203-208

\section{Information about author: Yaniuk N. V., Ph.D.,} Associate Professor of the Administrative and Financial Law Department Ivan Franko National University of Lviv 1, University St., Lviv, Ukraine

DOI https://doi.org/10.30525/978-9934-588-43-3/2.30 